\title{
Executive Pay and Firm Performance: Methodological Considerations and Future Directions
}

\author{
Beth Florin \\ Pearl Meyer \& Partners
}

\author{
Kevin F. Hallock \\ Cornell University and NBER
}

Douglas Webber

Cornell University

February 26, 2010

We are grateful to Sherrilyn Billger and Catherine McLean for helpful suggestions. We thank the Compensation Research Initiative at Cornell University for support. 


\begin{abstract}
This paper is an investigation of the pay-for-performance link in executive compensation. In particular we document main issues in the pay-performance debate and explain practical issues in setting pay as well as data issues including how pay is disclosed and how that has changed over time. We also provide a summary of the state of CEO pay levels and pay mix in 2009 using a sample of over 2,000 companies and describe main data sources for researchers. We also investigate what we believe to be at the root of fundamental confusion in the literature across disciplines - methodological issues. In exploring methodological issues, we focus on empirical specifications, causality, fixed-effects, first-differencing and instrumental variables issues. We then discuss two important but not yet well explored areas; international issues and compensation in nonprofits. We conclude by examining a series of research areas where further work can be done, within and across disciplines.
\end{abstract}


Executive compensation is a topic that has interested researchers for nearly a century. Bearle and Mean's (1932) pioneering discussion of the modern corporation, Robert's (1956) first empirical study, Murphy's (1985) first discussion of considering panel data, Jensen and Murphy's (1990) discussion of the way executives are paid, Hall and Liebman's (1998) study of the link between wealth and firm performance and a steady stream of academic papers since have focused on the link between pay of CEOs and corporate performance. This subject is perhaps even more relevant today with the dramatic changes in the economy and the outcry from various constituent groups to examine the pay of senior executive more closely. The subject has interested researchers from a variety of fields including Human Resource Management, Economics, Accounting, Finance, Law, Sociology, Psychology and Industrial Relations. It is remarkable that, although hundreds of papers have been written on the subject, there is no real consensus on the relationship between executive pay and firm performance. This is due, in part, to the diverse set of disciplines involved in the study, the wide variety of methods used to investigate the main questions and the diversity in knowledge about the institutions that matter in this area. This paper is an attempt to bridge these gaps and consolidate some of the understanding of this important issue.

This paper reviews some of the literature, documents the current empirical facts, explains the data available, discusses pay and performance, discusses the varied empirical methods and possible reasons for differences in "results" across studies, identifies international issues, explores the current regulatory environment, and considers avenues for future work in the area. The paper is almost exclusively focused on CEO pay, although there is some discussion of the top executive team. Although it should be clear from the context, in most 
instances when we say "executive" we primarily are referring to the CEO. The paper is not a comprehensive review of all of the literature on executive compensation, nor is it a review of the pay-for-performance literature and we apologize, in advance, to authors whose papers we have not discussed ${ }^{1}$. However, this paper highlights certain studies that are examples of the issues we explore.

In the next section we describe the CEO pay-for-performance debate and, in general terms, why it has not yet been resolved. Following that is another section, where we describe a series of important data issues. Part of the rise of the field has been due to public disclosure of executive compensation data in publicly-traded firms in the United States. However, there have been substantive changes in disclosure over time and we explore the implications of that for our work. We discuss types of executive compensation data and changes over time and then go on to describe the specific sources most frequently used by academics and practitioners today. We finally discuss pay levels and pay mix across a set of 2,108 CEOs using data from 2009 proxy statements.

We then have a section on "practical" matters of setting executive compensation and reasons why that may affect the pay-for-performance debate. This includes a discussion of "proxy advisory services" and the role they play in setting executive compensation.

We then follow with a discussion of methodological issues, which we feel are a central part of this work. In fact, we feel that issues of methodology are specifically important in this area of research since across (and within disciplines) researchers use similar, yet distinctly different empirical models and these can have profound implications for their findings. We feel that these considerations can help clarify past findings and perhaps suggest future directions. 
The particular functional-form of the empirical specifications used in the executive pay literature differ widely. We describe examples of each and discuss implications of these models for interpreting pay-for-performance measures. In fact, we believe that part of the problem in differing interpretations of pay-for-performance results come from problems in appropriately interpreting empirical models. This section includes discussion of the "right" functional form, "fixed-effect" and "first-difference" models, instrumental variables and the implications for executive compensation research, and a section on thinking about "causality". Next, we explore different measures of firm performance including accounting measures, financial measures, subjective measures and relative performance. We also include a discussion of the little-studied area of international compensation. Executive compensation in nonprofit organizations is also briefly discussed. As difficult as it may be to consider the pay of managers in for-profit firms, at least it is clear that there is a "bottom" line. This section describes compensation of senior managers in a variety of nonprofit organizations including nonprofit hospitals, labor unions and nonprofits in general. Finally we offer a concluding section where we summarize our work, discuss various new government reforms (including say-on-pay and managing risk) and offer a plan for future work in the area.

\section{A BRIEF HISTORY OF THE CEO PAY-PERFORMANCE DEBATE AND WHY IT ISN'T RESOLVED}

Summarizing the massive literature on the CEO pay-to-performance debate is not an easy task. However, in this section we offer a brief summary of some of the issues and findings over the past few decades. This will set the stage for our later discussion of functional forms, empirical problems and other issues. 
The study of executive compensation goes back at least to Roberts (1956) and even Bearle and Means (1932). There were also notable papers decades ago such as Masson (1971), and Lewellen and Hunstman (1970) and Coughlin and Schmidt (1985) among others. Although the field really took off with the availability and use of better data (both in terms of quantity and quality) and Murphy’s (1985) landmark study.

Murphy (1985) collected data on the compensation and performance of 461 executives at 71 firms over a number of years. But, rather than estimating simple cross-sectional relationships (which showed no relationship between CEO pay and performance) Murphy (1985), introduced "fixed-effects" models (described below) and found a strong relationship between pay and performance. This empirical method was not novel in economics at the time, but it had not been applied to the CEO pay literature and was an interesting and important advance for reasons we discuss below. Murphy (1985), documenting a relationship between pay and performance also wrote a paper in the Harvard Business Review at the time stating that "CEOs are worth every nickel they can get".

Five years later Jensen and Murphy (1990) wrote an important paper using firstdifference methods (also described below). In that paper, they found that for every $\$ 1000$ increase in shareholder value(measured as a change in the market value of equity), CEO pay went up by $\$ 3.25$. Their interpretation of this was that, although there was a relationship between pay and performance, the relationship was rather weak and could be strengthened. In part due to Jensen and Murphy's work, and due to calls from practitioners, this lead to the extraordinary rise in the use of stock and stock options in executive compensation contracts. Options and stock became much more important components of executive pay packages starting in the early $1990 \mathrm{~s}^{2}$. 
Later in the 1990s, Hall and Liebman (1998) asked whether CEOs were paid like "bureaucrats"? They collected unique data on stock and stock options (that were at the time not more formally disclosed) and found stronger relationships between pay and performance than found by Jensen and Murphy (1990), on the order of $\$ 5.29$ for every $\$ 1000$ increase in shareholder wealth. They conclude that while this may still seem like quite a weak relationship, their work suggests that even small changes in performance can have very large effects on the lifetime wealth of an executive.

More recently Bebchuk and Fried $(2004,2006)$ wrote a provocative book called "Pay Without Performance". This book carefully articulates the difference between the oftendiscussed "arm's-length bargaining" framework and what they call the "managerial power" perspective, where, in essence, boards are captured by CEOs. They discuss many reasons why they think the system for setting CEO pay needs reform ${ }^{3}$.

Answering the pay for performance debate in executive compensation is obviously a difficult question. There are many complications. For example, researchers use different data sources, companies have different compensation and business strategies (even in the same industry) and there are many potential factors that are not easily measured by academic researchers. However, one of the main reasons we think the debate has not yet been resolved is methodological issues which we explore in the rest of this paper. But, first we turn to some practical, institutional issues.

\section{DATA ISSUES}

In this section, we will outline several data issues that have confronted researchers who study executive compensation. This will include a discussion of the types of compensation 
data, Securities and Exchange Commission (SEC) rules changes on reporting compensation, and specific ways firms are required to report today. We will also discuss major sources of data used by practitioners and academics. We will then go on to briefly describe pay levels and pay mix for CEOs across industries and firm size from a set of 2,108 companies.

\section{Types of Executive Compensation Data and Changes Over Time}

One of the reasons for the meteoric rise in the number of papers published on executive compensation is the availability of data. Data on executive pay have been widely available since 1992, when the SEC through new disclosure rules required firms to report on top officer compensation in a systematic way. However, the way data were reported was not, until very recently (a 2006 SEC change that we discuss below), entirely satisfying in terms of really understanding the way executives were paid at a point in time. For example, prior to 2006, we may have known an executive's salary, bonus, the value of stock sold, and options exercised in a given year. However, those options and that stock may have been accumulated over many years so the information reported in a given year was a combination of some compensation for the most recent year (e.g. the salary) and stock and options accumulated for perhaps as long as a decade earlier. This may be one of the reasons researchers have had trouble linking pay to performance - since the performance may have been for a given year or the year prior while the pay was from a hybrid of data that may have covered a large number of years. We discuss this problem with the pay-performance relationship below.

Of course, there have been exceptional cases of authors who have gone to great lengths to collect data on executive compensation prior to the most recent SEC change. Examples include Murphy (1985) - perhaps the first real "classic" in the literature, Hall and Liebman (1998), and a more recent effort by Frydman and Saks (2010). In the first case, Murphy (1985) 
collected data from 76 manufacturing firms ( 71 were used in the analysis sample) to investigate the relationship between pay and performance. In the second, Hall and Liebman (1998) collected detailed data on stock options (that were not previously collected in one place) to demonstrate a relationship between ownership in firms and firm performance. Frydman and Saks (2010) is an ambitious example of careful data collection. In this paper, the authors investigate executive compensation from a set of firms from 1936 to 2005 . They find that the median real value of executive compensation was quite flat from the late 1940s through the 1970s, showing a weak overall link between CEO pay and firm growth. The collected the data by hand from company proxy reports from 1936 through 1991 and then used Execucomp (explained in more detail below) for data beyond 1991.

In 2006, the SEC began requiring publicly traded firms to disclose compensation for the CEO, Chief Financial Officer and three other most highly paid Named Executive Officers (NEOs). The new guidelines both clarified and standardized the elements of compensation as well as the time period for reporting. Among the information firms are now required to report are salary, bonus, non-equity incentive compensation, stock, stock options, changes in pension and non-qualified deferred compensation and other compensation. It is worth being clearer about these seven "main" components of compensation. Salary, of course, is the annual, fixed and guaranteed compensation for the executive. Bonus and non-equity incentive compensation are sometimes confused and, intuitively, both can be considered a type of "bonus". Strictly speaking, the bonus as listed in the table is formula-based pay beyond cash salary. On the other hand, non-equity incentive compensation can be both short-term or long-term pay that is based on some pre-set criteria (based on performance) whose outcome is uncertain. Stock compensation is the value of the stock granted over the prior year, as of the time it is granted. 
Stock options represent the value of the options granted over the prior year. Stock options pose a unique problem in valuing executive compensation contracts. The numbers included in firms' proxy statement "summary compensation tables" are accounting based numbers and do not necessarily reflect the value of the options at the time of the grant. Therefore, we recommend, and most researchers use the value of stock options from the stock option grant summary tables, which are also included in firm proxy statements ${ }^{4}$. Finally, "other" compensation refers to amounts of perquisites of $\$ 10,000$ or more or to tax gross-ups, company contributions for security, private use of aircraft, financial planning etc.

Table 1 is an example of a Summary Compensation Table for the General Electric for 2009. Several features of the table are noteworthy. The table lists compensation for the CEO, $\mathrm{CFO}$ and five other executives. As noted above, firms are required to list the $\mathrm{CEO}, \mathrm{CFO}$ and at least three others. One reason for listing more than five executives is the fact that some may have retired or otherwise left the firm during the year. Another (which is not the case for GE) is the example of "co-CEOs". It is also clear from the table that information is included for each of the last three years. This is the third year since the new SEC regulations came into place so is, therefore, the first time outsiders can see three years of compensation information all in the same proxy statement. Table 1 also shows the seven different pay components that are required to be reported for each executive. ${ }^{5}$. It is also interesting to see that at GE, the CEO was not the highest paid executive (at least as reported in the most recent proxy statement.) In fact, as reported in Table 1, three others earned more than the CEO. Hallock and Torok (2010) report that of 2,108 firms they studied, in only $81 \%$ was the CEO was the highest paid executive. There are many reasons why the CEO may not be the highest paid, including one-time signing bonus, larger than normal option grants (commonplace when hiring new executives) or 
severance, for example. In the case of GE in Table 1, the CEO received no bonus, option awards, or non-equity incentive payout. All three executives who were paid more than the CEO had non-zero values for each of these elements of compensation. Finally, it is interesting to see, in Table 1, the diversity of compensation across pay elements and to see the diversity of pay within the top management team.

\section{Main Data Sources Used By Academics and Practitioners}

There are three major commercial data sources on executive pay at the person-level and firm-level that are now relatively widely used. The first, ExecuComp (Executive Compensation data base) is produced by Standard and Poor's Corporation and is surely the most widely used source of data for research on executive pay by academics. This source has data available from 1992 - present on the compensation of the top five highest paid employees of U.S. publicly traded firms (who have managerial control) in roughly 1,500 firms per year. These firms include those listed in the Standard and Poor's 500, the Standard and Poor's SmallCap 600, and the Standard and Poor's MidCap 400. The data source starts in 1992 which was (until three years ago) the last time there was a major change in executive pay disclosure rules.

Two other commercial executive pay sources are Equilar and Salary.com. Each also provides comprehensive data sets of executive compensation but have a larger focus on marketing to the for-profit firm and compensation consulting market. These sources are frequently used by compensation design practitioners and consultants to help design executive pay plans (and to set comparison groups). Some academics are using data from these sources but they are much more widely used by practitioners ${ }^{6}$. The three data sources fundamentally report the same basic information. Equilar and Salary.com started after Execucomp and 
perhaps academics have used Execucomp in part due to inertia. It may also be due to cost considerations. Equilar and Salary.com provide many interface features for, for example, making comparison groups easy and for presentation purposes. Most academic don't need these features of their products.

\section{Pay Levels and Pay Mix Across Industries and Size Groups in 2009}

This section is designed to set the basic context for the kinds of pay levels, mix (types of pay across different components of compensation), and pay distributions ${ }^{7}$. The data for this section are from Salary.com and comprise 2,108 publicly traded firms who reported executive compensation information in their proxy statements as of June 2009.

Figure 1 displays two measures of compensation. The first is defined as "cash" and is the sum of salary, bonus and non-equity incentive. The second measure is "total compensation". This is defined as the sum of salary, bonus, non-equity incentive, stock, stock options, change in pension and non-qualified deferred earnings and other. Figure 1 displays the median cash compensation and total compensation for CEOs by industry for each of 22 different industries. Notice the dramatic heterogeneity in compensation levels for the median CEO across industries. For example, the median CEO in Commercial Banks earned about $\$ 581,000$ in cash pay and $\$ 906,000$ in total compensation. At the other extreme is the Food \& Tobacco industry where the median CEO earned $\$ 2.28$ million in cash compensation and $\$ 5.80$ million in total compensation. These statistics alone mask another level of heterogeneity. Consider, for example, the Food and Tobacco industry (numbers not reported in tables or figures). There, the CEO at the $10^{\text {th }}$ percentile earned $\$ 575,000$ in cash pay and $\$ 901,632$ in total compensation but the CEO at the $90^{\text {th }}$ percentile of that industry earned $\$ 5.6$ million in cash and \$14.9 million in total compensation. 
It may seem strange that Commercial Banks represent the industry with the lowest paid median CEO. It must be kept in mind that these numbers do not control for the size of the organization. In fact, there are a large number of Commercial Banks in the sample and many of them are quite small. Organization size (e.g. revenue, employees) is highly positively correlated with the compensation of the senior leaders. Figure 2 is a case in point. In this figure, the 2,108 companies are sorted by their level of annual revenue. The smallest 10 percent are in decile 1, the next ten percent in decile 2, up to the largest 10 percent in decile 10. It is clear that the median level of compensation rises monotonically with organization size. In particular, for the smallest 10 percent of companies (those with annual revenues below $\$ 155$ million, the median CEO earned $\$ 522,000$ in cash pay and $\$ 1.04$ million in total compensation. This rises monotonically up to the largest 10 percent of firms (those with annual revenues above $\$ 9.6$ billion) where the median CEO earned $\$ 3.03$ million in cash compensation and \$11.3 million in total compensation. Again, the median masks the larger distribution. For example, for the largest 10 percent of companies, the CEO at the $10^{\text {th }}$ percentile earned $\$ 4.2$ million in total compensation but the CEO at the 90th percentile earned \$25 million in total compensation.

Understanding the levels of pay for CEOs is interesting and important but misses a more interesting and important part of executive compensation, how executives are paid. In particular, we now explore how executives are paid across the seven components of compensation discussed above. Figure 3 shows a great deal of heterogeneity across compensation components by industry. In fact, it is quite reasonable to expect diversity in compensation mix within industry. Figure 4 reports the pay mix distribution on firm size deciles (the same deciles reported in Figure 2). Notice that as the average firm gets larger a 
smaller fraction of the total compensation is paid in salary and a larger fraction is paid in stock and stock options. For example, for the smallest 10 percent of companies, the fraction of total compensation paid in salary is 43.91 percent but for the largest 10 percent of companies, the fraction of total compensation paid in salary is only 13.5 percent. Conversely, the average CEO in the smallest 10 percent of companies earned $35.56(21.55+14.01)$ percent of his or her total compensation in stock and options. But the average CEO in the largest 10 percent of companies earned $53.05(24.81+28.24)$ percent of his or her total compensation in stock and stock options.

Now that we have set the stage for where the data come from and how CEOs are paid in the United States today, we turn to some of the practical issues in setting CEO pay..

\section{PRACTICAL ISSUES IN CEO PAY}

In this section, we briefly describe some of the institutions that are important in setting CEO and other senior executive compensation in the United States. In particular, we briefly mention the role of the Board of Directors, the Compensation Committee of the board and the role of executive compensation consultants. We go on to highlight some of what are known as "proxy advisory services" and the roles they play in executive compensation in the United States today.

\section{What Happens in Board Rooms and How Pay is Set}

Very little academic work formally discusses the role of the Board of Directors or the Compensation Committee of the Board, even though these are the organizations that formally set pay of executives in publicly traded companies ${ }^{8}$. The Board is formally responsible for executive compensation but most boards have a Compensation Committee (a sub-set of the 
board) who set pay of the CEO and his or her top team. Hallock, Tonello and Torok (2010) show that the median Board across 10 deciles of firm size have between 8 and 12 members. The median compensation of Board members from the top decile of firms in 2009 is was \$191,000 (Hallock, Tonello and Torok, 2010).

Formally the Board is required to set compensation of the executive and expected to be "independent". Many Boards hire compensation consultants to facilitate the development of compensation strategy and bring relevant data to help frame pay decisions for CEOs and other top managers. These compensation professionals consider the firm's business strategy, compensation strategy, industry, organization size, the composition of pay of "like" firms and make recommendations to the board.

Many in the press, government and academia (most notably Bebchuk and Fried, 2006) have been critical of the formal system that exists in the United States for setting pay for executives. Bebchuk and Fried (2006) argue that there is not "arms-length" negotiation between boards and the CEO over executive contracts. On the other hand, they argue that boards (and consultants) are "captured" by CEOs who try to surround themselves with those who advocate for higher pay or more favorable compensation mix. To ameliorate this potential conflict, some have argued that compensation consultants to boards should be "independent". An example of this is large multi-purpose HR consulting companies that provide executive compensation consulting services, while at the same time providing other HR and benefits administration and consulting services. Since the revenue to the HR consulting firm from providing executive compensation consulting services may be only a small fraction of the total revenue received from that particular firm, some argue that the executive compensation 
consultants may want to give the CEO higher pay in implicit exchange for the large volume of other services provided to their company.

\section{Proxy Advisory Services, Investors and Executive Pay}

Many "proxy advisory” services have emerged in the past decade including Risk Metrics (formerly Institutional Shareholder Services), Glass Lewis and GovernanceMetrics International. These organizations market and sell their services to smaller investors, firms and institutional investors. Among the services they provide is a type of "scorecard" by firm for thousands of publicly traded companies. They might, for example make recommendations on votes before the company, provide information about directors and also provide some information about executive compensation.

The kinds of information these organizations provide about executive compensation is varied but quite limited. For example, in 2008, the typical Risk Metrics report was on the order of 15 pages, one of which was devoted to executive compensation. This included a total of three charts showing (1) the CEO's total compensation relative to a peer group median, (2) salary, bonus and non-equity compensation of the CEO relative to the median of a peer group and (3) stock and option awards of the CEO relative to a peer group. A comparable 10 page report from Glass Lewis for the same time period devoted one page to executive compensation. This included (1) a grade (A - F) and historical "compensation score," (2) two charts comparing various components of compensation with sector groups and (3) a chart on shareholder wealth and business performance. GovernanceMetrics International for the same time period produced a three page report for each firm that was entirely devoted to executive compensation. This included some charts on pay levels plotted against shareholder returns, 
comparisons to industry, charts on returns and pay, relative to industry, a chart on pay mix and a one-page narrative.

While we think these companies provide easily understood summaries to investors and firms with respect to CEO pay, firm performance and comparison groups, the analysis is extremely simple and largely reports numbers straight out of individual firm proxy statements (except for some median comparisons by "industry"). This serves as an example where the chasm between academic work on executive compensation and the practical world is enormous. Almost none of what has been learned in the past decades about executive compensation, pay or performance is included in these sources.

\section{METHODOLOGICAL ISSUES}

In this section, we explore two main issues. First, there have been a wide variety of empirical specifications in diverse research on pay and performance for CEOs of publicly traded firms. We explore the diverse set of specification and how one might make different interpretations of results depending on specification used. Second, we discuss the issue of causality in empirical research on the pay-to-performance relationship for CEOs. Our intent is to help consolidate understanding and hopefully help researchers synthesize the diverse results.

\section{Empirical Specifications}

One of the difficulties in comparing the results of all papers in the executive pay literature is that very few of them estimate the exact same model. While there does not appear 
to be a consensus on the "best" specification, there are many commonalities which appear over and over again.

We begin our discussion with how compensation is actually defined. The most popular definition is to use "total compensation" (see our discussion above) as the dependent variable, but many studies also focused on option (Alamazan, Hartzell and Starks, 2005), bonus (Fattorusso, Skovorodo, Buck, and Bruce, 2007), or basic cash compensation (Comprix and Muller, 2006). One desirable trend in many papers is the analysis of several models, defining executive compensation differently each time, demonstrating their results are robust to multiple forms of pay. Clearly, it is natural to expect certain forms of pay to be more strongly related to certain measures of firm performance than others. For example, it is reasonable to expect that stock and stock option compensation is more highly correlated with firm performance than salary.

One important feature of a paper's empirical specification is the functional form chosen to represent key variables. Specifically, the natural log transformation, which is used to deal with skewed data, is commonly applied to the dependent and many independent variables. While the interpretation of coefficients is slightly less straightforward following a logtransformation, it is especially important for valid statistical inference when dealing with variables with a very skewed distribution such as compensation and sales data (Hallock, 1997 provided evidence that the log-transformation is important in executive compensation settings). Unfortunately, slightly less than half of the empirical papers we surveyed used the logtransformation on the dependent variable. This omission has the potential to seriously alter the magnitude and interpretation of results. 
One generally agreed-upon aspect is the need to control for a firm's size when estimating an executive's pay. While not unanimous, nearly every study we examined controls for size in some way. By far, the two most common ways to control for firm size were to use a measure of sales (revenue) or assets held by a firm. Another popular measure is the total number of employees. These three variables are commonly highly correlated, except in banks and other financial institutions, where assets are obviously substantially higher than sales and employees, relative to many other industries.

When examining the link between pay and performance, a crucial choice authors must make is how exactly to define performance. There are a number of accepted ways this is done, although the most convincing studies present the results for several different measures (Abowd, 1990). The most common performance measure is a firm's return on assets, followed by the return on common stock. Other measures include the return on equity, shareholder wealth, or firm profits. This point will be revisited in more detail later in this section.

One important factor when looking at the effect of performance on pay, which only about a third of studies control for, is the variability of performance. The intuition being that some industries naturally have very volatile performance indicators, likely weakening the pay(observed) performance relationship because a high (or low) value may not necessarily be a signal of the executive's ability but rather a random shock. Studies which control for volatility generally use either the standard deviation (or variance) of performance (e.g. Garen, 1994) or the cumulative distribution function (CDF) of performance (e.g. Garvey and Milbourn, 2003; or Dee, Lulseged and Nowin, 2005). The CDF appears to be the better option since it is a measure of the entire distribution of performance rather than just the spread. 
One class of variables conspicuously absent from the majority of models is demographic information about the executive (Kostiuk, 1990; Hallock, 1997; and Bertrand and Mullainathan, 2001; and Bertrand and Hallock, 2001 are notable exceptions). Very few studies include standard control variables such as gender, race, or age. Age and tenure (and their squared terms) seem particularly important to include in any sort of wage equation (as they are standard practice dating back to the original Mincerian wage equations). However, whether due to data constraints or omission, these variables appear in less than a fifth of the empirical studies we examined.

Another important feature of many papers (particularly those without firm fixed-effects) is the inclusion of some measure of corporate governance (such as Core, Holthausen and Larcker, 1999; and Cornell, Marcus and Tehramian, 2008). Evidence suggests that the strength of a firm's corporate governance is positively related to the association between pay and performance.

While not all studies use panel data, and some that do don't take full advantage of their panels, the papers which fully utilize panel data tend to be the most convincing works. To begin our brief panel discussion, it seems that including industry fixed-effects are a bare minimum (this is true in a cross-sectional framework as well). Nearly every paper with firms in different industries either includes industry indicators or runs separate regressions for different industries. The most common panel data approach taken by studies in this literature is a firstdifference approach (Boschen and Smith, 1995; Anderson and Bizjak, 2003; and Becker, 2006 just to name a few), with relatively few papers using a firm/executive fixed-effect strategy (Such as Aggarwal and Samwick, 1999, 2003; Cichello, 2005; and Murphy, 1985). In many cases, this is likely due to a lack of data or insufficient variation within executive 
pay/performance measures. That said, the paper's which are able to employ a fixedeffects/differencing strategy are most likely to come close to obtaining the best estimates of the "true" causal effect of performance on executive pay. We discuss this in more detail below in a section on causality.

In total, about half of the empirical papers we examined attempt to fully exploit the panel nature of their data, to varying degrees of success. The first-difference model was used by about a third of our sample of empirical studies, with CEO/firm fixed-effects used by slightly less than a fifth of papers. A discussion of which of these approaches is more appropriate (they are equivalent only in the case of two time periods) is beyond the scope of our project, and rests on distributional assumptions and serial correlation of the error term.

To give the reader an idea of the relative frequency of the approaches to estimating executive compensation, we have compiled Table 4, which breaks down the studies by type of model (fixed-effects, first difference, etc.) and whether the log-transformation was applied to the dependent variable. It should be noted that the 49 studies which appear in the table represent only a sample of the executive pay literature (we believe a representative sample of the top research), and there are undoubtedly a number of other articles which could appear in the table but are not included.

\section{Thinking More Seriously About Causality}

The following section is meant as a brief introduction to the problem of establishing causality in empirical work, with specific emphasis on the CEO pay-to-performance problem. One of the reasons that there is such diversity in the "answer" to the pay-to-performance problem is the diversity of empirical methods and the dearth of papers that consider the issue of 
causality at all. For example, trying to consider causal relationships in a simple cross-section using OLS specifications is clearly impossible. Given the wide range of statistical approaches and results in the executive pay literature, we feel that a having a basic notion of causality is crucial for the reader to evaluate the relative merits of each paper. We have attempted to make this discussion as accessible as possible to readers across fields.

The ultimate goal of most empirical research is to find the true causal effect of some independent variable $\mathrm{X}$ on an outcome $\mathrm{Y}$. In the rare case that $\mathrm{X}$ is exogenously determined (randomly assigned), a simple regression of $\mathrm{Y}$ on $\mathrm{X}$ will give us the causal impact of $\mathrm{X}$ on $\mathrm{Y}$. In the case of the pay for performance literature, this would be the equivalent of estimating equation (1): where $\alpha$ is a constant, $\beta$ is the change in pay associated with a one unit change in performance, and $\varepsilon$ is a random error term.

(1) CEO Pay $=\alpha+\beta$ Performance $+\varepsilon$

The reason this equation is never estimated is because in this model we view performance as endogenous. By this we mean that performance measures were not randomly assigned to executives, and that the same process which determines performance may also be related to the process which determines executive compensation (in a statistical sense, this means that performance is correlated with the error term).

A commonly discussed analogy is to think of the effect of schooling on future earnings (Griliches, 1979, Card, 1995). It is an accepted fact that people with higher levels of schooling have higher incomes, but it is also generally true that, on average, individuals with higher innate ability have higher levels of schooling. So we must then ask how much of the increase 
in income is due to increased schooling and how much is due to a higher innate ability or some other unobserved variable related to schooling.

The most common way to address this issue is to estimate equation (2), where we have added a vector of control variables $\mathrm{Z}$ along with their associated coefficients $\delta$

(2) $\mathrm{CEO}$ Pay $=\alpha+\beta$ Performance $+\mathrm{Z} \delta+\varepsilon$

These control variables may include measures such as the size of the firm, the age of the executive, or any other factors which we believe has an impact on an executive's pay. In this case, for us to assign a causal interpretation to the coefficient on performance, we are assuming that performance is randomly assigned after conditioning on the covariates in $\mathrm{Z}$.

If performance cannot be considered exogenous, then the results we obtain will be considered correlational rather than causal. Hence, we could say that a one unit increase in performance is on average associated with a $\beta$ increase in compensation. We would however be unable to make the causal claim that if we increased a performance measure by one unit then we would observe an increase in pay of $\beta$. This is an important distinction because it is possible to have a strong correlation between performance and pay, yet there to be no causal link. Unfortunately, many authors in the executive pay literature fail to make this distinction, discussing their results in a causal context when they have not fully addressed potential endogeneity concerns.

Establishing a causal link is not an easy task, and many will argue is impossible without a randomized experiment. There are several approaches however which can greatly improve the accuracy of the basic regression estimates mentioned above. 


\section{First-Difference and Fixed-Effects}

The essence of the first-difference and fixed-effect methods is to exploit the panel nature of certain datasets, namely the fact that we may observe the same firm/executive many different times. For instance, assume that there is some fixed but unobserved factor which is correlated with both executive compensation and firm performance (this could be the executive's ability, firm culture, etc.) denoted by $\gamma$. If we observe many executives in periods $t$ and $\mathrm{t}-1$, then assume that the true wage equations are as follows.

(3) CEO Payt-1 $_{t} \alpha+\beta$ Performance $_{t-1}+Z_{t-1} \delta+\gamma+\varepsilon_{t-1}$

(4) CEO Payt $=\alpha+\beta$ Performance ${ }_{t}+Z_{t} \delta+\gamma+\varepsilon_{t}$

Subtracting equation (3) from equation (4) will then give us equation (5), which we can estimate since all variables in (5) are observed, and an unbiased estimate of $\beta$. This is known as the first-difference method for obvious reasons. The most famous example of this in the empirical executive compensation literature is Jensen and Murphy (1990). The fixed-effect method is illustrated in equation (6), where instead of taking the difference between two periods we include a dummy variable for each CEO/firm in the sample. Interestingly, in the two-period case, the first-difference and fixed-effect methods are algebraically identical. In panels with more than two years the two methods differ, but the statistical assumptions underlying the difference between these methods is beyond the scope of this chapter (although should be taken seriously by the researcher). Murphy's (1985) classic is the first example of this method in the empirical CEO pay literature.

(5) CEO Pay $\mathrm{t}_{\mathrm{t}}-$ CEO Pay $\mathrm{t}_{\mathrm{t}-1}=\beta\left(\right.$ Performance $_{\mathrm{t}}-$ Performance $\left._{\mathrm{t}-1}\right)+\left(\mathrm{Z}_{\mathrm{t}}-\mathrm{Z}_{\mathrm{t}-1}\right) \delta+\varepsilon_{\mathrm{t}}-\varepsilon_{\mathrm{t}-1}$ 
(6) CEO Pay $=\alpha+\beta$ Performance + Z $\delta+$ Firm $+\varepsilon$

It is always important to note in any model where the identification is coming from (exactly which observations are contributing to which estimates). In a standard OLS regression context, all observations contribute equally to the estimated parameters. However, in a firstdifference/fixed-effect context, the parameters are estimated based off of changes within a firm. In other words, if a firm's performance does not change, then it will not contribute to the estimate of $\beta$. Practically, this is important because if there is not much variation in a dataset, the estimates could be driven entirely by a small number of firms, or could even be the result of random noise.

While it is not always possible to control for firm fixed-effects, including a set of industry dummy variables (assuming the dataset being used contains executives from more than one industry) is an absolute must. To not control for industry would implicitly assume that, conditional on the covariates, firms in different industries have the exact same pay structure.

\section{Instrumental Variables}

Sometimes researchers do not have panel data available to them, or do not believe the assumptions implicit in a fixed-effects framework (these are discussed briefly below in the Empirical Problems section). In these cases, an Instrumental Variables (IV) framework can theoretically identify causal effects. We will not go into the mechanics of IV, but the intention is to find an exogenous variable which does not belong in the compensation equation correlated with the potentially endogenous variable of interest (performance), and identify $\beta$ from this exogenous variation. 
The best example in the executive compensation literature is from Bertrand and Mullainathan (2001). In their study of oil companies, they use exogenous shocks to the price of oil to instrument for performance. In this example, these shocks clearly do not belong in the compensation equation, but are highly correlated with performance indicators, making them an ideal instrument.

\section{Empirical Problems}

The two methods for establishing causality outlined above are by no means a panacea, and have many problems which must be addressed in practice. In fact, many researchers use these methods blindly and are lulled into a false sense of security that all problems have been solved via use of these methods. Clearly that is not the case. For a first-difference/fixed-effects approach, having a large dataset is crucial, since multicollinearity is exacerbated in this setting. In an IV framework, strong instruments are often hard to find, and must be rigorously justified in order to be accepted as valid.

When surveying the pay-for-performance, or any empirical literature for that matter, it is important to keep this causal thought process in mind. Many studies will come to wildly different conclusions, for a variety of different reasons, and this line of thinking is key to discerning between the studies you should believe and those you shouldn't.

\section{Performance Metrics}

As mentioned before, a wide variety of measures, and categories of measures, are used to proxy for performance throughout the executive pay literature. The main categories of performance metrics are accounting, economic/market, relative performance, and subjective. The most commonly used measure, an accounting measure, is the after-tax return on assets 
(Used by Bebchuk and Grinstein, 2005; Carpenter and Sanders, 2002; Chhaochharia and Grinstein, 2009; and David, Kochhar and Levitas, 1998 to name a few). This variable is preferable both because of its availability and straightforward interpretation/construction ${ }^{9}$.

The next most common measure of performance falls under the market category, shareholder return on common stock. Defined below ${ }^{10}$, many researchers (Such as Cosh and Hughes, 1997; Hall and Knox, 2004; or Harford and Li, 2007) prefer this metric because it most directly measures the progress of the chief mission of the firm, to financially benefit its shareholders. Another accounting measure, the after-tax return on equity, is also widely used (Hambrick and Finkelstein, 1995; and Leonard 1990).

As one might expect, the link between executive pay and performance appears to be influenced somewhat by the performance metric used. For instance, Abowd (1990) found that the link was much stronger for market measures than for accounting measures.

Another class of performance metrics deals with the possibility that firms reward (or punish) their executives based on how the firm performs relative to other comparable firms in the same industry. The most common way to test for the presence of relative performance evaluation is simply to control for the difference between a firm's performance measure and the market average for that same measure. Two of the papers which focus explicitly on this type of performance metric are Antle and Smith (1986), and Gibbons and Murphy (1990).

As mentioned earlier, some studies explore the link between pay and performance using less quantitative and more subjective measures of performance. Denis, Hauna and Sarin (2006) find a positive link between allegations of securities fraud and executive stock options. In a similarly themed paper, Efendi, Srivastava and Swanson (2007) find a positive correlation 
between misstated financial statements and executive stock options which were "in the money". Finally, McGuire, Dow and Argheya (2003) find that executive compensation is unrelated to various measures of "social performance".

\section{INTERNATIONAL ISSUES}

Very little is known about international issues in compensation generally and in executive compensation in particular. Part of the problem with the study of executive compensation and the pay-for-performance issue across nations is related to differences in disclosure and, therefore, availability of data across countries. There are two main issues we discuss here. First is why there may be differences in compensation across countries. Second, is the state of the pay-to-performance literature using various within-country data sources.

\section{CEO Pay Differences Across Countries}

Making CEO pay comparisons across countries is extremely difficult. Fortunately there is one source that we know of that sheds some light on this issue. In a recent paper, Gabaix and Landier (2008) have some data collected from the consulting company Towers Perrin on average levels of pay for CEOs across various countries as well as average levels of company size in those countries.

We have reproduced one of their figures as Figure 5. The horizontal axis in the figure is the average log company size in terms of company annual revenue. The vertical axis is the average log total compensation for CEOs. The points represent the different countries. For example, it is clear from the figure that CEOs in the United States are paid more, on average, than CEOs in any other country. At the same time, firms in the United States are larger (in terms of annual revenue) than firms in any of the other countries. The figure also has an OLS 
regression line plotted through it. Intuitively this suggests, that if there is a "world" market for pay and if firm size is the only relevant characteristic in predicting pay, then countries with points above the line have CEOs who are, on average, "over paid," relative to their average firm size and countries with points below the line have CEOs who are, on average, "under paid," relative to their average firms size.

This figure is interesting since it tells us several things. First, perhaps one of the reasons CEOs in the United States are paid so much, relative to their counterparts in other countries, is due to the fact that companies in the United States are so large ${ }^{11}$. Second, even though firm size is one important predictor of CEO pay (e.g. Rosen, 1992), firm size doesn't completely explain why CEOs in the United States are paid so much more than elsewhere. We should note that the data for this figure were provided by one Human Resource consulting firm and their clients may not be representative of the universe of firms.

\section{International Pay and Performance Within Countries}

Several authors have tried to investigate the CEO pay-to-performance relationship, or CEO pay more generally, in countries other than the United States. We highlight some of these studies here. In this section we will note studies from the UK, Germany, Japan, Sweden and China.

The one country (other than the United States) where most work has been done is the UK. In one paper Conyon and Murphy (2000) find that CEOs are paid more in the US than the UK but much of that is due to stock based pay which has a stronger link to performance. Conyon and Sadler (2001) find that in the UK, the sensitivity of pay-for-performance increases with organization levels. They go on to show a link between stock ownership and subsequent 
performance. In a more recent paper, Fattoruso, Skovoroda, Buck and Bruce (2007) use UK data and find little link between bonus and firm performance. They argue that bonuses are, therefore, in essence "guaranteed". Finally, Girma, Thompson and Wright (2007) find little link between CEO pay and performance, on average, in the UK. However, they find that for firms with many employees, there is a small pay-to-performance link.

In Germany, Edwards, Eggert, Weichenrieder (2009) find that firms with low concentrations of investor ownership have only a small link between CEO pay and firm profits. However, those with highly concentrated ownership have no link at all. Using some data from the UK and Germany, but in a mostly theoretical paper, Bruce, Buck and Main (2005) discuss region specific social norms, which others have argued are important to international compensation but very difficult to operationalize. In Japan, Kato and Kubo (2006) find a strong link between CEO pay and firm performance using a ten-year panel, especially if using accounting measures of performance. Becker (2006) finds that, in Sweden, incentives decrease with CEO wealth. Finally Firth, Fung and Rui (2007) study China.

Clearly we need more research on the link between pay for CEOs and firm performance internationally. Given the difficulties in matching data sources across firms, the differences in disclosure requirements and tax rules across countries, and vastly different social norms in some countries, this may prove to be difficult yet interesting work.

\section{OTHER ORGANIZATIONAL FORMS}

Studying executive compensation in the for-profit world is clearly difficult, as this paper has stressed. However, in for-profit firms the "bottom line" is quite clear. On the other hand, in nonprofit organizations, it is not always clear what the "bottom line" mission of the organization really is. If we thought the "true" measure of performance for a particular 
nonprofit was "alleviating poverty" or "helping those in need" or "caring" or "trustworthiness", how would we measure this?

A series of recent papers have begun to investigate the compensation of managers in nonprofit organizations. Oster (1998) and Hallock (2002) both show that the strong link between firm size and executive pay which exists in for-profit firms is also present in nonprofits. Additionally, Hallock (2002) points out that the revenue from government grants has no effect on executive compensation among nonprofits once firm fixed-effects are controlled for. The same study also notes that a higher proportion of compensation at non-profits is in the form of benefits rather than salary.

As noted in both Oster (1998) and Hallock (2002), determinants of pay at non-profits vary greatly by the type industry or charity. Examples include the nursing home industry as studied by Weisbrod and Schlesinger 1986, or universities which are examined by Ehrenberg, Cheslock and Epifantseva 2002. Looking specifically at nonprofit hospitals, Bertrand, Hallock and Arnould (2005) examine the link between executive pay and profit-based performance measures following the introduction of HMOs into the market. They find that HMO penetration strengthened the link between pay and profit-based performance measures, and also increased the likelihood of turnover in less profitable non-profit hospitals.

Some types of non-profits have more easily measureable performance measures. In their recent examination of the compensation structure for the heads of labor unions, Hallock and Klein (2009) find that union membership and the wage of union members is strongly related to the pay of the union executive. 
Finally, Frye, Nelling and Webb (2006) use a matching strategy to compare firms who are "socially responsible" to the more traditional for-profit firm. While the analysis does not explicitly concern nonprofits, the basic idea that some firms may put more emphasis on performance measures not easily observable still holds. Consistent with the non-profit literature, this study finds that "socially responsible" firms (as measured by the Domini Social Index) have a much weaker link between pay and financial performance, and that option grants do not appear to induce the same risk taking behavior in socially responsible firms that is observed in non-socially responsible firms.

\section{CONCLUDING COMMENTS AND RESEARCH QUESTIONS FOR THE FUTURE}

This paper is an investigation of the pay-for-performance link in executive compensation. In particular we have explored data issues including how pay is disclosed and how that has changed over time, a summary of the state of CEO pay levels and pay mix in 2009 using a sample of over 2,000 companies, described main data sources, documented main issues in the pay-performance debate and explained practical issues in setting pay. We also investigated what we believe to be at the root of fundamental confusion in the literature across disciplines - methodological issues. In exploring methodological issues, we focused on empirical specifications, causality, fixed-effects, first-differencing and instrumental variables issues. We ended with a discussion of two important but not yet well explored areas; international issues and compensation in nonprofits.

We think there are several promising avenues for future work in executive compensation. The dramatic advances in data availability, consistency and quality will likely lead to less diversity in results in future studies. We hope that researchers across fields take 
advantage of this. We also believe that a serious exchange of ideas on methods across (and within) disciplines needs to happen. We find it odd that researchers across disciplines have such trouble talking to, understand or working with those outside their niche areas.

Additionally, we think that the walls between academic research and practice should be brought down generally, but in the area of executive compensation in particular.

There are also a host of regulatory issues on the horizon and we suspect (hope!) that some will lead to the potential for interesting exogenous and unexpected changes that could help us to better focus on issues of causality we mention above. In addition, certain legislation pending in Congress right now - including legislation related to "Say on Pay" could be very interesting. "Say on Pay" refers to the opportunity for a firm's shareholders to have an annual, non-binding, vote on the compensation of the firms' senior executives. We suspect that study of this sort of proposal could lead to clever new research on executive compensation across disciplines. We also believe more work on issues of corporate governance would be investigated, including work on the separation of the CEO and Chair of the Board. The difficult issue of severance and so-called "change-in-control" agreements are also gaining increased attention by practitioners and we suspect will garner more attention from academics soon.

There is too little work on international issues in compensation and in executive compensation in particular. This is due, in part, to data availability problems and in part due to the inherent difficulties in doing work across countries and cultures. We hope that in the near future researchers in the future embrace the challenge of working on international issues.

Another area we feel is ripe for exploration and analysis by academic researchers is that of "risk". While there has been some work in this area, the recent financial crisis has focused 
this discussion much more sharply. We expect analysis focusing on risk, risk-adjusted-pay and the like will occupy many of colleagues in the future.

This paper is focused on many areas of executive compensation including the pay-forperformance debate, current issues and the state of pay today, compensation internationally but had a large focus on methodological issues and cross-disciplinary problems. Our hope is that this work will not only help researchers focused on CEO pay and performance but also motivate researchers in other areas of Human Resources to explore outside their own discipline and work more closely with those from other fields. 


\section{REFERENCES}

Aboody, D., Barth, M., \& Kasznik, R. (2006). Do firms understate stock option-based compensation expense disclosed under SFAS 123, Review of Accounting Studies, 11(4), 429461.

Abowd, J. (1990). Does performance-based managerial compensation affect corporate performance? Industrial and Labor Relations Review, 43, 52-73.

Aggarwal, R., \& Samwick, A. (2003). Performance incentives within firms: The effect of managerial responsibility, Journal of Finance, 58(4), 1613-1649.

Aggarwal, R., \& Samwick, A. (1999). Executive compensation, strategic competition, and relative performance evaluation: Theory and evidence, Journal of Finance, 54(6), 1999-2043.

Aggarwal, R., \& Samwick, A. (1999). The other side of the trade-off: The impact of risk on executive compensation," Journal of Political Economy, 107(1), 65-105.

Ahn, J., \& Hallock, K. (2003). Relative pay within companies, Manuscript, University of Illinois

Almazan, A., Hartzell, J., \& Starks, L. (2005). Active institutional shareholders and costs of monitoring: Evidence from executive compensation, Financial Management, 34(4), 5-34. 
Anderson, R., \& Bizjak, J. (2003). An empirical examination of the role of the CEO and the compensation committee in structuring executive pay, Journal of Banking and Finance, 27(7), 1323-1348.

Ang, J.,. Lauterbach, B., \& Vu, J.( 2003). Efficient labor and capital markets: Evidence from CEO appointments," Financial Management, 32(2), 27-52.

Antle, R., \& Smith, A. (1986). An empirical investigation of the relative performance evaluation of corporate executives, Journal of Accounting Research, 24(1), 1-39.

Baker, G., \& Hall, B. (2004). CEO incentives and firm size, Journal of Labor Economics, 22(4), 767-798.

Bearle, A., \& Means, G. (1932). The Modern Corporation and Private Property. Transaction Publishers.

Bebchuk, L., \& Fried, J. (2004). Pay Without Performance: The Unfulfilled Promise of Executive Compensation. Harvard University Press.

Bebchuk, L., \& Fried, J. (2006). Pay without performance: Overview of the issues, Academy of Management Perspectives, 20(1), 5-24. 
Bebchuk, L. \& Grinstein, Y. (2005). The growth of executive pay, Oxford Review of Economic Policy, 21(2), 283-303.

Becker, B. (2006). Wealth and executive compensation, Journal of Finance, 61(1), 379-397.

Bertrand, M., \& Hallock, K. (2001). The Gender Gap in Top Corporate Jobs, Industrial and Labor Relations Review, 55(1), 3-21.

Bertrand, M., \& Mullainathan, S. (2001). Are CEOs Rewarded for Luck? The Ones Without Principals Are, The Quarterly Journal of Economics, 116(3), 901-932.

Bertrand, M., Hallock, K. \& Arnould, R. (2005). Does managed care change the mission of nonprofit hospitals? Evidence from the Managerial Labor Market, Industrial and Labor Relations Review, 58(3): 494-514.

Boschen, J., \& Smith, K. (1995). You can pay me now and you can pay me later-the dynamicresponse of executive-compensation to firm performance, Journal of Business, 68(4), 577-608.

Bruce, A., Buck, T., \& Main, B. (2005). Top executive remuneration: A view from Europe, Journal of Management Studies, 42(7), 1493-1506. 
Card, D. (1995). Using Geographic Variation in College Proximity to Estimate the Return to Schooling". In Christofides, L., Grant, E., \& Swidinsky, R., Aspects of Labor Market Behaviour: Essays in Honour of John Vanderkamp. Toronto: University of Toronto Press.

Carpenter, M.,. \& Sanders, W. (2002). Top management team compensation: The missing link between CEO pay and firm performance? Strategic Management Journal, 23(4), 367-375.

Chen, C., Steiner, T., \& Whyte, A. (2006). Does stock option-based executive compensation induce risk-taking? An analysis of the banking industry, Journal of Banking and Finance, $30(3), 915-945$.

Cichello, M. (2005). The impact of firm size on pay-performance sensitivities, Journal of Corporate Finance, 11(4), 609-627.

Comprix, J., \& Muller, K. (2006). Asymmetric treatment of reported pension expense and income amounts in CEO cash compensation calculations, Journal of Accounting and Economics, 42, 385-416.

Conyon, M., \& Sadler, G. (2001). Executive pay, tournaments and corporate performance in UK firms," International Journal of Management Reviews, 3(2), 141-168.

Conyon, M., \& Murphy, K. (2000). The prince and the pauper? CEO pay in the United States and United Kingdom, Economic Journal, 110(467), Special Issue F, F640-F671. 
Core J., and Guay, W. (1999). The use of equity grants to manage optimal equity incentive levels, Journal of Accounting and Economics, 28(2), 151-184.

Core, J., Holthausen, R., \& Larcker, D. (1999). Corporate governance, chief executive officer compensation, and firm performance, Journal of Financial Economics, 51(3), 371-406.

Cornett, M., Marcus, A., \& Tehranian, H. (2008). Corporate governance and pay-forperformance: The impact of earnings management, Journal of Financial Economics, 87(2),357373.

Cosh, A. \& Hughes, A. (1997). Executive remuneration, executive dismissal and institutional shareholdings, International Journal of Industrial Organization, 15(4), 469-492.

Coughlin, A., \& Schmidt, R. (1985). Executive compensation, management turnover and firm performance, Journal of Accounting and Economics 7, 43-66.

Cunat, V., \& Guadalupe, M. (2009). Globalization and the provision of incentives inside the firm, Journal of Labor Economics, Forthcoming.

David, P., \& Levitas, K. (1998). The effect of institutional investors on the level and mix of CEO compensation, Academy of Management Journal, 41(2), 200-208. 
Dee, C., Lulseged, A., \& Nowlin, T. (2005). Executive compensation and risk: The case of internet firms, Journal of Corporate Finance, 12(1), 80-96.

Denis, D., Hanouna, P., \& Sarin, A. (2006). Is there a dark side to incentive compensation? Journal of Corporate Finance, 12(3), 467-488.

Devers, C.,, Cannella A., Reilly, G. \& Yoder, M. (2007). Executive compensation: A multidisciplinary review of recent developments, Journal of Management, 33(6), 1016-1072.

Edwards, J., Eggert, W., \& Weichenrieder, A. (2009). Corporate Governance and Pay for Performance: Evidence from Germany, Economics of Governance, 10, 1-26.

Efendi, J., Srivastava, A., \& Swanson, E. (2007). Why do corporate managers misstate financial statements? The role of option compensation and other factors, Journal of Financial Economics, 85(3), 667-708.

Ehrenberg, R., Cheslock, J., \& Epifantseva, J. (2001). Paying Our Presidents: What Do Trustees Value? The Review of Higher Education, 25(1): 15-37.

Fattorusso, J., Skovoroda, R., Buck, T., \& Bruce, A. (2007). UK executive bonuses and transparency - A research note, British Journal of Industrial Relations, 45(3), 518-536. 
Firth, M., Fung, P., \& Rui, O. (2007). How ownership and corporate governance influence chief executive pay in China's listed firms, Journal of Business Research, 60(7), 776-785.

Frye, M., Nelling, E., \& Webb, E. (2006). Executive compensation in socially responsible firms, Corporate Governance-An International Review, 14(5), 446-455.

Frydman, R., \& Saks, R. (2010). Executive Compensation: A New View from a Long Term Perspective, Review of Financial Studies, forthcoming.

Gabaix, X. \& Landier, A. (2008). Why has CEO pay increased so much?, Quarterly Journal of Economics, 123, 49-100.

Garen, J. (1994). Executive-compensation and principal-agent theory," Journal of Political Economy, 102(6), 1175-1199.

Garvey, G. \& Milbourn, T. (2003). Incentive compensation when executives can hedge the market: Evidence of relative performance evaluation in the cross section, Journal of Finance, 58(4), 1557-1581.

Gibbons, R., \& Murphy, K. (1990). Relative Performance Evaluation for Chief Executive Officers, Industrial and Labor Relations Review, 43(3), s30-s51. 
Girma, S., Thompson, S., \& Wright, P. (2007). Corporate governance reforms and executive compensation determination: Evidence from the UK, Manchester School, 75(1), 65-81.

Griliches, Z. (1976). Wages of Very Young Men, Journal of Political Economy, 84, 569-586.

Hall, B., \& Knox, T. (2004). Underwater options and the dynamics of executive pay-toperformance sensitivities, Journal of Accounting Research, 42(2), 365-412.

Hall, B., \& Murphy, K. (2002). Stock options for undiversified executives, Journal of Accounting and Economics, 33(1), 3-42.

Hall, B., \& Liebman, J. (1998) Are CEOs Really Paid Like Bureaucrats? Quarterly Journal of Economics, 123(3), 653-92.

Hallock, K. (2002). Managerial pay and governance in American nonprofits, Industrial Relations, 41(3), 377-406.

Hallock, K. (1997). Reciprocally interlocking boards of directors and executive compensation," Journal of Financial and Quantitative Analysis, 32(3), 331-344.

Hallock, K. (1999). Dual Agency: Corporate Boards with Reciprocally Interlocking Relationships. in Carpenter, J., \& Yermack, D. Executive Compensation and Shareholder Value: Theory and Evidence, (55-75). Kluwer. 
Hallock, K., \& Klein, F. (2009). Executive Compensation in American Unions, Compensation Research Initiative Working Paper, 2009-007

Hallock, K., \& Olson, C. (2010). New Data for Answering Old Questions Regarding Employee Stock Options. in Abraham, K., Spletzer, J., \& Harper, M. Labor in the New Economy, University of Chicago Press for the National Bureau of Economic Research.

Hallock, K., \& Torok, J. (2010) Top Executive Compensation in 2009, Research Report R1454-10-RR, The Conference Board, NY, NY.

Hallock, K., Tonello, M., \& Torok, J. (2010). Directors' Compensation and Board Practices in 2009, The Conference Board, NY, NY.

Hambrick, D., \& Finkelstein, S. (1995). The effects of ownership structure on conditions at the top-the case of CEO pay raises, Strategic Management Journal, 16(3), 175-193.

Harford, J., \& Li, K. (2007) Decoupling CEO wealth and firm performance: The case of acquiring CEOs, Journal of Finance, 62(2), 917-949.

Hartzell, J., \& Starks, L. (2003). Institutional investors and executive compensation,” Journal of Finance, 58(6), 2351-2374.

Jensen, M., \& Murphy, K. (1990). Performance Pay and Top Management Incentives, Journal of Political Economy, 98(2), 225-64. 
Kato, T., \& Kubo, K. (2006). CEO compensation and firm performance in Japan: Evidence from new panel data on individual CEO pay, Journal of the Japanese and International Economies, 20(1), 1-19.

Kay, I., \& Van Putten S., (2007). Myths and Realities of Executive Pay, Cambridge University Press.

Kostiuk, P. (1990). Firm Size and Executive Compensation. Journal of Human Resources 25(1):90-105.

Lambert, R., Larcker, D., \& Verrecchia, R. (1991). Portfolio considerations in valuing executive compensation,.Journal of Accounting Research 29, 129-149.

Leonard, J. (1990) Executive pay and firm performance," Industrial and Labor Relations Review, 43(3), Special Issue, S13-S29.

Lewellen, W., \& Huntsman, B. (1970). Managerial Pay and Corporate Performance, American Economic Review, 60, 710-720.

Lippert, R., \& Moore, W. (1994). Compensation contracts of chief executive officers-determinants of pay-performance sensitivity, Journal of Financial Research, 17(3), 321-332.

Masson, R., (1971). Executive Motivations, Earnings, and Consequent Equity Performance, Journal of Political Economy, 79(6), 1278-1292 
McGuire, J., Dow, S., \& Argheyd, K. (2003). CEO incentives and corporate social performance, Journal of Business Ethics, 45(4), 341-359.

Murphy, K., (1985). Corporate Performance and Managerial Remuneration: An Empirical Analysis, Journal of Accounting and Economics, 7(1-3), 11-42.

Murphy, K., (1999). Executive compensation. (2485-2563). in Ashenfelter, O., \& Card, D. Handbook of Labor Economics, volume 3B, Elsevier Science Publishers,

Oster, S. (1998). Executive compensation in the nonprofit sector, Nonprofit Management \& Leadership, 8(3): 207-221.

Oyer, P. (2004). Why do firms use incentives that have no incentive effects?, Journal of Finance, 59(4), 1619-1649.

Rajgopal, S., Shevlin, T., \& Zamora, V. (2006). CEOs' outside employment opportunities and the lack of relative performance evaluation in compensation contracts," Journal of Finance, 61(4), 1813-1844.

Roberts, D. (1956). A General Theory of Executive Compensation Based on Statistically Tested Propositions, Quarterly Journal of Economics 70,: 270-94. 
Rosen, S. (1992). Contracts and the Market for Executives. (181-211). in Werin, L., \& Wijkander, H. Contract Economics, Oxford: Blackwell.

Weisbrod, B., \& Schlesinger, M. (1986). Public, private, nonprofit ownership and the response to asymmetric information: The case of nursing homes. In Rose-Ackerman, S., The Economics of Nonprofit Institutions: Studies in Structure and Policy: 133-151. New York: Oxford University Press. 
FIGURE 1. CEO Compensation by Industry

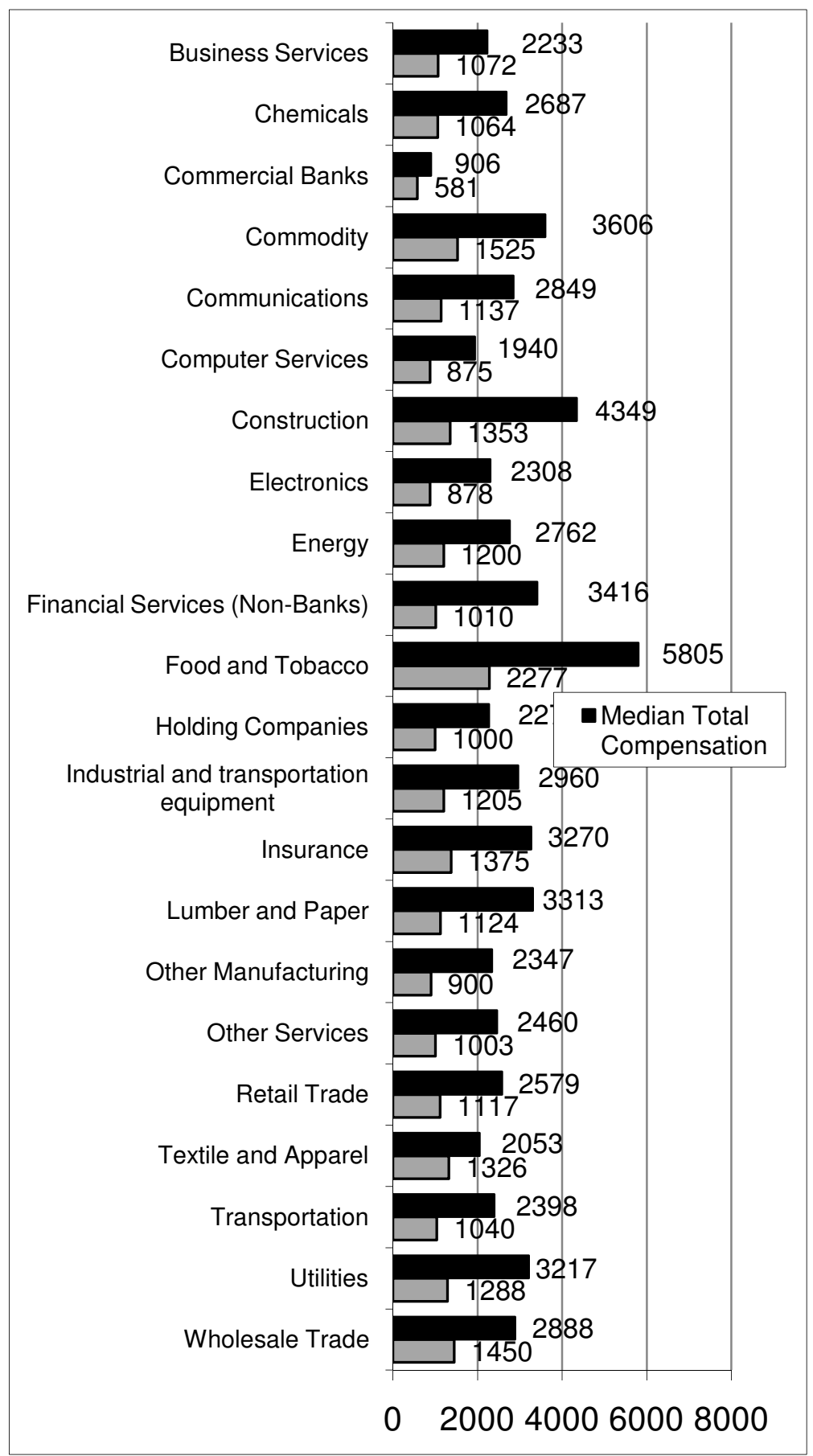

Note: From Hallock and Torok (2010). Data from Salary.com. 
FIGURE 2. CEO Compensation by Company Size

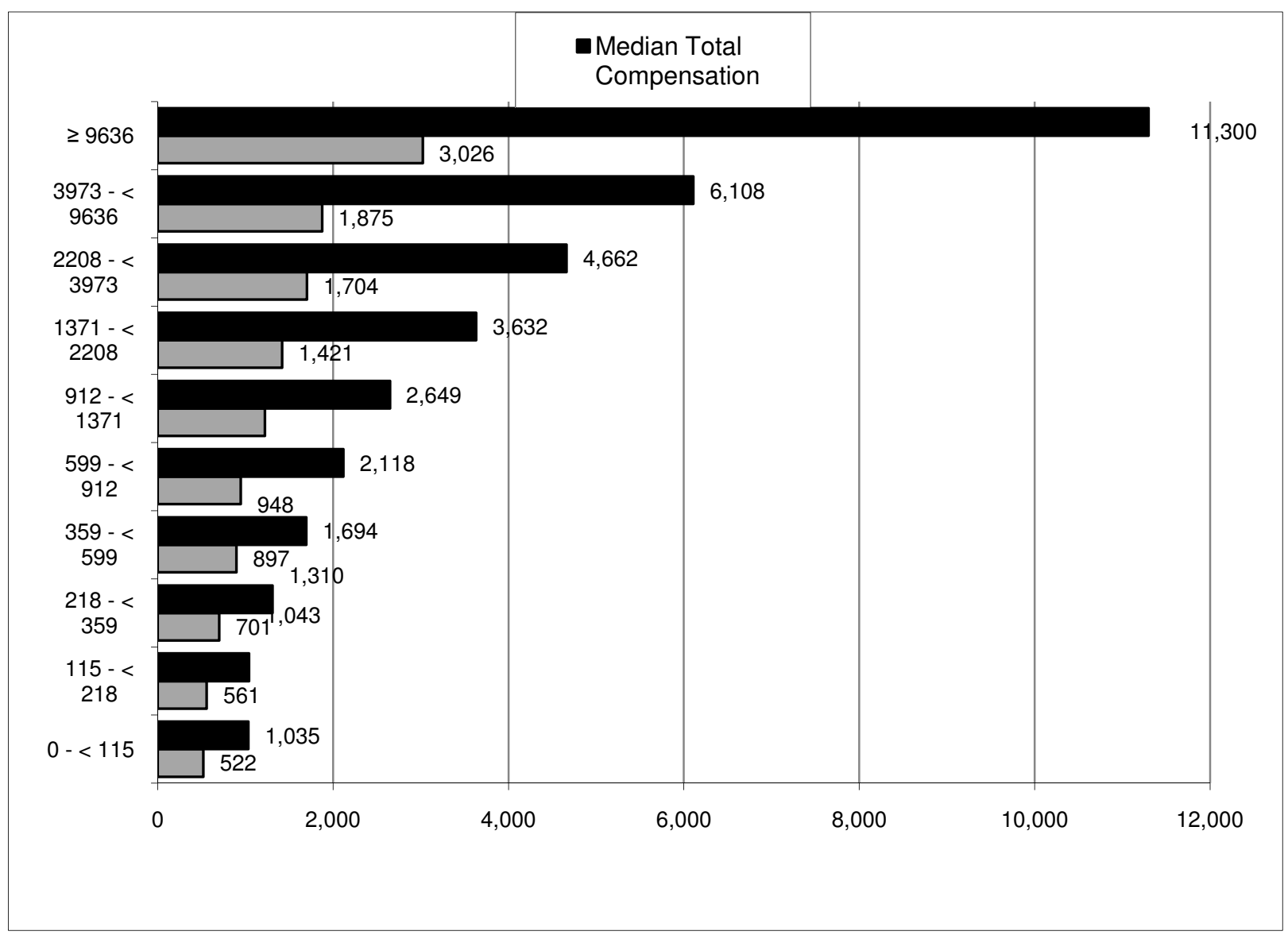

Note: From Hallock and Torok (2010). Data from Salary.com. 
FIGURE 3. CEO Compensation Mix by Industry

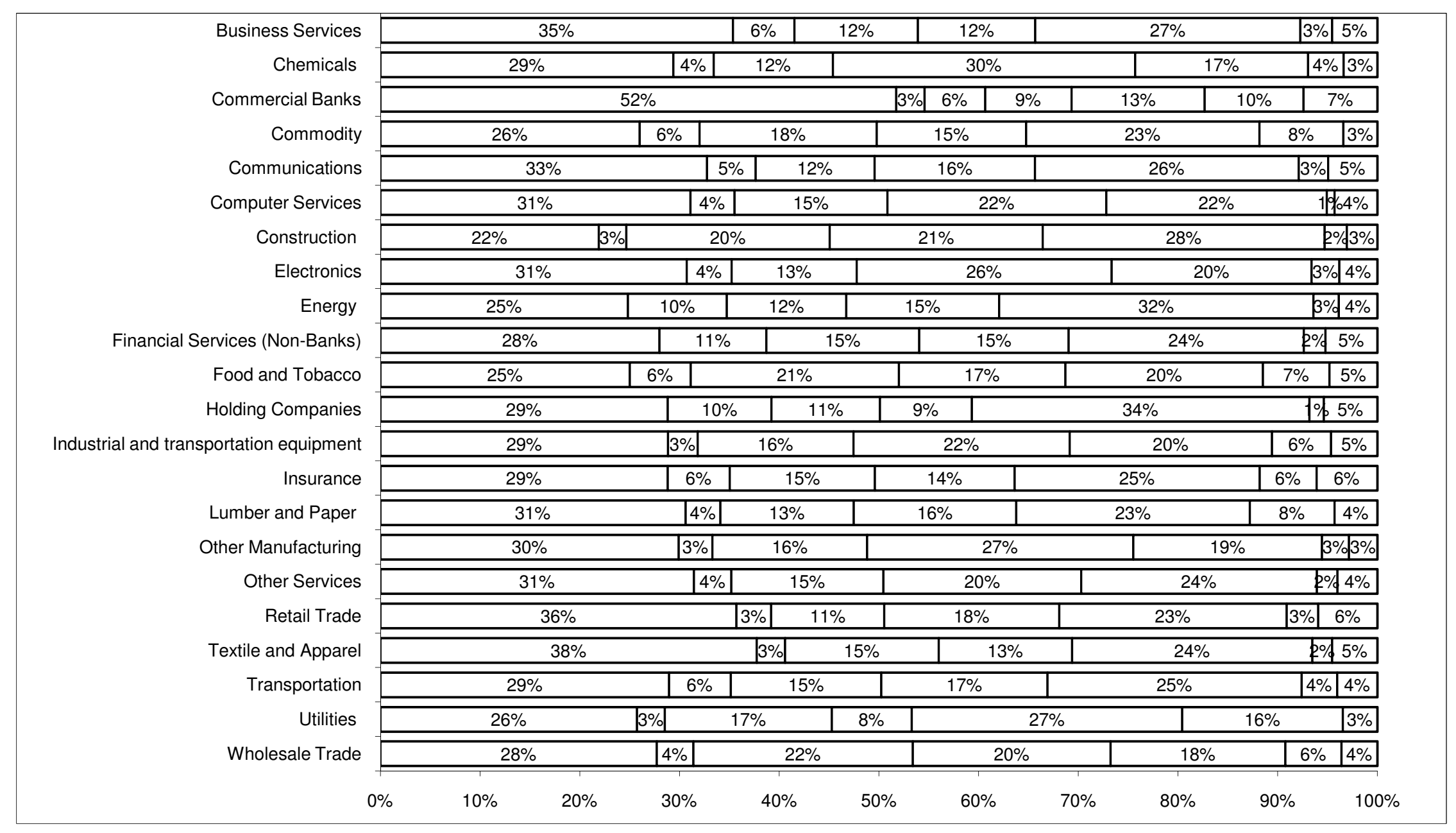

Note: From Hallock and Torok (2010). Data from Salary.com. 


\section{FIGURE 4. CEO Compensation Mix by Size Group}

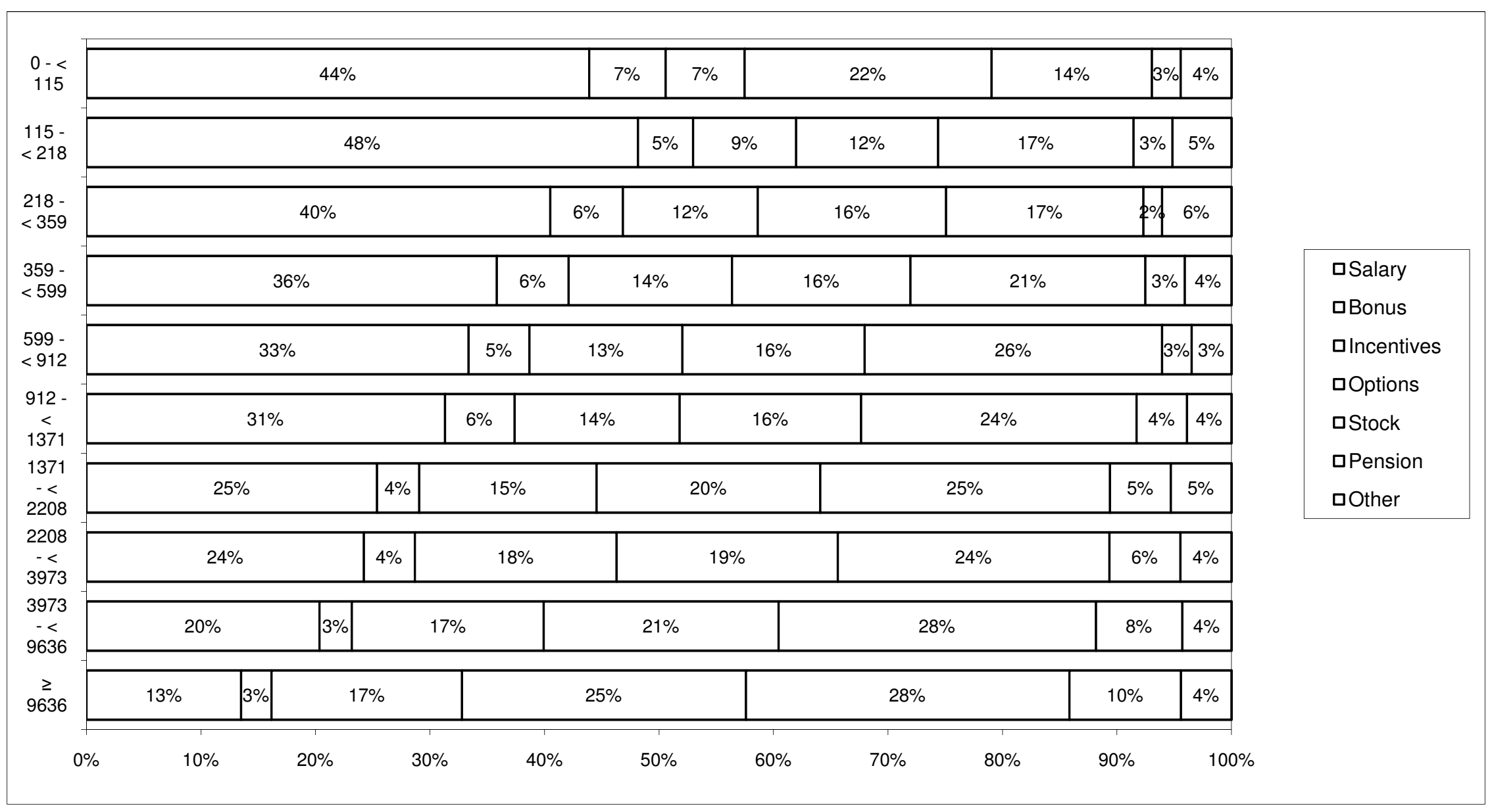

Note: From Hallock and Torok (2010). Data from Salary.com. 
FIGURE 5.

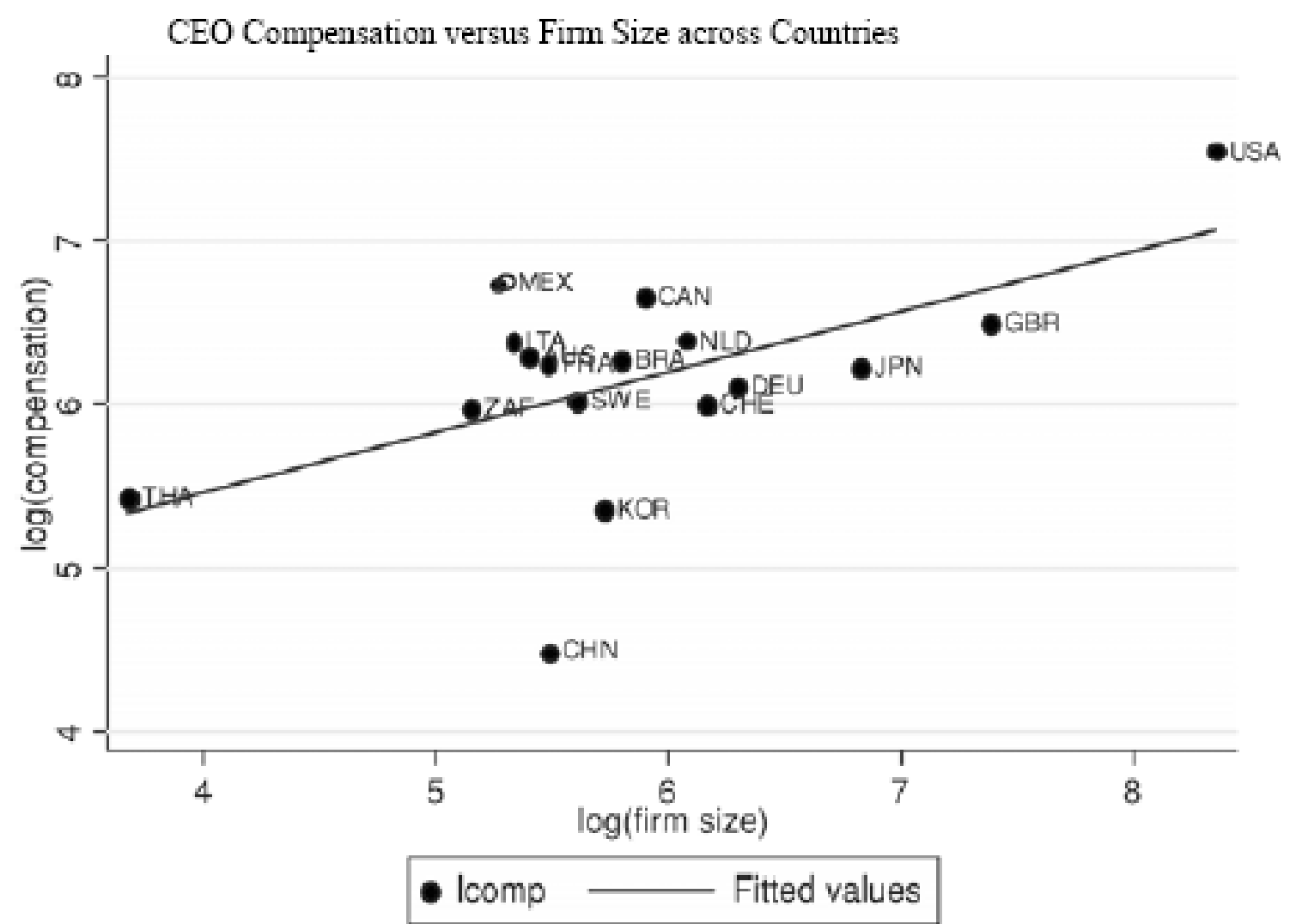

From Gabaix and Landier (2008) 
TABLE 1. Proxy Statement for General Electric Company

2008 Summary Compensation Table

\begin{tabular}{|c|c|c|c|c|c|c|c|c|c|}
\hline $\begin{array}{l}\text { Name and } \\
\text { Principal Positon }\end{array}$ & Year & Salary ${ }^{1}$ & Bonus & $\begin{array}{c}\text { Stock } \\
\text { Awards }^{2}\end{array}$ & $\begin{array}{c}\text { Option } \\
\text { Avards }{ }^{4} \\
\end{array}$ & $\begin{array}{l}\text { Non-Equity } \\
\text { Incentive Plan } \\
\text { Compensation }\end{array}$ & $\begin{array}{l}\text { Chenge in } \\
\text { Pension Value } \\
\text { and } \\
\text { Nonqualified } \\
\text { Dele rred } \\
\text { Compensation } \\
\text { Earnings }{ }^{5} \\
\end{array}$ & $\begin{array}{c}\text { All Other } \\
\text { Comsensation }\end{array}$ & Total \\
\hline Jeffrey P. Immeli, & 2008 & $\$ 3,300,000$ & & $\$ 3,860,318_{3}$ & - & $\$$ & $3, E 63,466$ & 372,819 & $\$ 14,096,603$ \\
\hline Chairman of the Board and CEO & $\begin{array}{l}2007 \\
2006\end{array}$ & $\begin{array}{l}3,300,000 \\
3,300,000\end{array}$ & $\begin{array}{l}5800,000 \\
5,000,000\end{array}$ & $\begin{array}{r}9,802,359_{3} \\
7,404,209_{3}\end{array}$ & $\begin{array}{r}\$ 214,664 \\
574,322\end{array}$ & $\begin{array}{l}0 \\
0\end{array}$ & $\begin{array}{r}78,290 \\
1,036,908\end{array}$ & $\begin{array}{l}396,237 \\
548,013\end{array}$ & $\begin{array}{l}19,591,580 \\
17,86 \varsigma, 452\end{array}$ \\
\hline $\begin{array}{l}\text { Keith S. Sherin, } \\
\text { Vico Chairman and CFO }\end{array}$ & $\begin{array}{l}2008 \\
2007 \\
2006\end{array}$ & $\begin{array}{r}\$ 1,500,000 \\
1,354,167 \\
1,225,000 \\
\end{array}$ & $\begin{array}{r}\$ 2550,000 \\
3,000,000 \\
2550,000 \\
\end{array}$ & $\begin{array}{r}\$ 2,987,493 \\
3,076,095 \\
2,808,919 \\
\end{array}$ & $\begin{array}{r}\$ 1,597,637 \\
1,714,833 \\
2,225,749 \\
\end{array}$ & $\begin{array}{lr}\$ 2,555,300 \\
\\
\\
0 \\
0 \\
\end{array}$ & $\begin{array}{r}\text { \$ } 2,503,541 \\
1,281,453 \\
1,664,398 \\
\end{array}$ & $\begin{array}{l}288,718 \\
275,430 \\
308,222 \\
\end{array}$ & $\begin{array}{r}\$ 13,982,589 \\
10,701,948 \\
10,682,288 \\
\end{array}$ \\
\hline $\begin{array}{l}\text { MchaelA.Naal } \\
\text { Vice Chaiman }\end{array}$ & $\begin{array}{l}2008 \\
2007 \\
2006\end{array}$ & $\begin{array}{r}\$ 1,650,000 \\
1,550,000 \\
1,400,000\end{array}$ & $\begin{array}{r}\$ 2900,000 \\
3880,000 \\
3300,000\end{array}$ & $\begin{array}{r}\$ 3,512,898 \\
4,212,201 \\
3,906,929\end{array}$ & $\begin{array}{r}\$ 1,475,645 \\
1,457,839 \\
1,759,672\end{array}$ & $\begin{array}{r}\$ \quad 2,933,900 \\
0 \\
0\end{array}$ & $\begin{array}{l}3,484,939 \\
2,979,130 \\
3,032,927\end{array}$ & $\begin{array}{l}344,044 \\
343,674 \\
294,872\end{array}$ & $\begin{array}{r}\$ 16,301,726 \\
14,422,844 \\
13,694,400 \\
\end{array}$ \\
\hline $\begin{array}{l}\text { John G. Rice, } \\
\text { Vice Chairman }\end{array}$ & $\begin{array}{l}2008 \\
2007 \\
2006 \\
\end{array}$ & $\begin{array}{r}\$ 1,650,000 \\
1,550,000 \\
1,400,000 \\
\end{array}$ & $\begin{array}{r}\$ 2700,000 \\
3.000,000 \\
2550,000 \\
\end{array}$ & $\begin{array}{r}\$ 3,659,090 \\
4,406,900 \\
4,122,437 \\
\end{array}$ & $\begin{array}{r}\$ 1,597,637 \\
1,714,833 \\
2,225,749 \\
\end{array}$ & $\begin{array}{rr}\$, 615,400 \\
0 \\
0 \\
\end{array}$ & $\begin{array}{r}3,328,715 \\
1,852,735 \\
2,183,677 \\
\end{array}$ & $\begin{array}{l}261,073 \\
393,825 \\
335,836 \\
\end{array}$ & $\begin{array}{r}\$ 18,811,815 \\
12,918,293 \\
12,817,729 \\
\end{array}$ \\
\hline $\begin{array}{l}\text { Brackett B. Dennisto }, \\
\text { SenibrVice President, Gereral Counsel } \\
\text { and Secretary }\end{array}$ & 2008 & $\$ 1,200,000$ & $\$ 1.850,000$ & $\$ 2,284,110$ & $\$ 1,239,568$ & \$ $\quad 4,000,200$ & $1,432,870$ & 250,857 & $\$ 12,257,605$ \\
\hline $\begin{array}{l}\text { David R. Nissen, } \\
\text { Forme President \& } \\
\text { CEO, GE Mlone; }\end{array}$ & 2008 & $\$ 1,350,000$ & $\$ 1,3 \cdot 0,000$ & $\$ 2,777,594$ & $\$ 2,731,013$ & $\$ \quad 4,169,500$ & $5,811,944$ & 190,426 & $\$ 22,440,477$ \\
\hline $\begin{array}{l}\text { Robsit C. Wright } \\
\text { Forme Vico Chaiman }\end{array}$ & $\begin{array}{l}2008 \\
2007 \\
2006\end{array}$ & $\begin{array}{r}\$ 916,667 \\
2,750,000 \\
2,500,000\end{array}$ & $\begin{array}{r}\$ 2783,000 \\
7.590,000 \\
6900,000\end{array}$ & $\begin{array}{r}-\overline{-} \\
\$ 1,943,665 \\
2,516, \overline{7} 12\end{array}$ & $\begin{array}{r}-\overline{-} \\
\$ 1,303, \mathrm{co5} \\
2,473,683\end{array}$ & $\begin{array}{r}\$ \quad 10,1<8,300 \\
0 \\
0\end{array}$ & $\begin{array}{lr}\$, 208,099 \\
\\
\\
\\
2,072,075 \\
2,422,714\end{array}$ & $\begin{array}{l}2,080,058 \\
1,314,0) 5 \\
1,010,730\end{array}$ & $\begin{array}{r}\$ 17,136,124 \\
15,972,750 \\
17,82 \xi, 889\end{array}$ \\
\hline
\end{tabular}

Note: Table from 2009 proxy statement of General Electric Company. 
Table 2. CEO Compensation by Industry

\begin{tabular}{|c|c|c|c|c|c|c|c|c|c|c|c|c|c|}
\hline & & \multicolumn{6}{|c|}{ Cash Compensation } & \multicolumn{6}{|c|}{ Total Compensation } \\
\hline & $\mathrm{N}$ & $10^{\text {th }}$ & $25^{\text {th }}$ & Mean & Median & 75th & 90th & $10^{\text {th }}$ & $25^{\text {th }}$ & Mean & Median & 75th & 90th \\
\hline Chemicals & 183 & 463,040 & 661,770 & $1,585,984$ & $1,063,750$ & $1,966,500$ & $3,526,250$ & 823,005 & $1,403,982$ & $4,666,154$ & $2,686,526$ & $6,454,073$ & $11,500,000$ \\
\hline Commercial Banks & 185 & 332,083 & 402,500 & 696,411 & 581,250 & 875,000 & $1,158,041$ & 437,261 & 580,432 & $1,762,620$ & 905,673 & $1,895,970$ & $3,493,447$ \\
\hline Commodities & 85 & 678,501 & 961,299 & $1,867,734$ & $1,524,583$ & $2,434,725$ & $3,284,000$ & $1,102,336$ & $1,686,500$ & $5,099,530$ & $3,606,402$ & $6,353,118$ & $10,800,000$ \\
\hline Communications & 78 & 654,711 & 780,000 & $1,585,526$ & $1,137,002$ & $1,732,500$ & $3,577,845$ & 819,035 & $1,518,311$ & $4,293,980$ & $2,849,066$ & $5,615,136$ & $11,900,000$ \\
\hline Computer Services & 137 & 370,000 & 555,024 & $1,220,244$ & 875,308 & $1,375,350$ & $2,671,250$ & 589,629 & $1,132,758$ & $3,285,691$ & $1,939,824$ & $3,845,512$ & $7,676,077$ \\
\hline Construction & 26 & 833,750 & $1,000,000$ & $2,100,333$ & $1,353,457$ & $2,386,318$ & $5,005,000$ & $1,705,216$ & $2,252,217$ & $5,297,176$ & $4,349,201$ & $7,411,561$ & $11,000,000$ \\
\hline Electronics & 153 & 395,159 & 550,000 & $1,223,686$ & 878,333 & $1,427,375$ & $2,548,000$ & 638,707 & $1,256,280$ & $3,277,515$ & $2,307,811$ & $3,979,451$ & $7,614,834$ \\
\hline Energy & 97 & 465,500 & 646,154 & $1,628,969$ & $1,199,756$ & $2,025,597$ & $4,400,600$ & 838,168 & $1,292,547$ & $5,011,330$ & $2,761,803$ & $6,986,162$ & $16,200,000$ \\
\hline Financial Services (Non-Banks) & 58 & 500,000 & 800,000 & $1,860,484$ & $1,009,856$ & $2,740,276$ & $4,950,000$ & 840,944 & $1,254,669$ & $4,619,841$ & $3,416,057$ & $7,606,430$ & $15,100,000$ \\
\hline Food and Tobacco & 50 & 575,000 & $1,147,342$ & $2,922,108$ & $2,277,237$ & $4,046,612$ & $5,614,329$ & 901,632 & $2,025,222$ & $6,946,929$ & $5,804,652$ & $9,575,570$ & $14,900,000$ \\
\hline Holding Companies & 109 & 416,678 & 652,000 & $1,222,678$ & $1,000,000$ & $1,590,750$ & $2,330,144$ & 865,876 & $1,307,296$ & $3,036,322$ & $2,271,405$ & $4,053,217$ & $6,983,402$ \\
\hline Industrial and transportation equipment & 162 & 450,000 & 717,750 & $1,841,272$ & $1,204,883$ & $2,250,000$ & $4,000,002$ & 769,648 & $1,399,934$ & $4,999,320$ & $2,959,994$ & $6,875,570$ & $13,000,000$ \\
\hline Insurance & 89 & 612,435 & 894,072 & $1,993,162$ & $1,375,000$ & $2,839,000$ & $4,100,000$ & 941,741 & $1,830,011$ & $5,683,356$ & $3,269,665$ & $7,325,265$ & $14,900,000$ \\
\hline Lumber and Paper & 40 & 602,077 & 788,987 & $1,373,753$ & $1,124,018$ & $1,692,627$ & $2,691,200$ & 936,277 & $1,393,705$ & $3,588,637$ & $3,313,487$ & $5,167,598$ & $6,929,589$ \\
\hline Other Manufacturing & 132 & 479,938 & 631,222 & $1,277,607$ & 900,000 & $1,708,600$ & $2,501,325$ & 803,130 & $1,169,791$ & $3,831,050$ & $2,346,803$ & $4,958,694$ & $7,682,034$ \\
\hline Other Services & 91 & 500,000 & 800,000 & $1,308,878$ & $1,003,167$ & $1,600,000$ & $2,163,333$ & 836,708 & $1,192,087$ & $3,530,677$ & $2,459,920$ & $4,387,239$ & $6,765,583$ \\
\hline Retail Trade & 127 & 437,396 & 700,000 & $1,553,112$ & $1,116,926$ & $1,700,000$ & $3,167,087$ & 657,296 & $1,330,447$ & $4,186,537$ & $2,579,077$ & $5,259,613$ & $9,182,022$ \\
\hline Textile and Apparel & 20 & 654,647 & 852,332 & $1,505,563$ & $1,325,500$ & $2,292,103$ & $3,477,798$ & 984,558 & $1,450,150$ & $3,268,828$ & $2,053,119$ & $6,072,780$ & $8,106,963$ \\
\hline Transportation & 59 & 429,504 & 640,000 & $1,516,370$ & $1,040,000$ & $1,800,126$ & $3,600,000$ & 710,625 & $1,405,963$ & $3,941,940$ & $2,398,471$ & $5,293,130$ & $7,904,901$ \\
\hline Wholesale Trade (S) & 53 & 605,000 & 891,033 & $1,774,548$ & $1,450,059$ & $2,075,000$ & $2,841,266$ & $1,185,812$ & $1,629,529$ & $3,575,034$ & $2,888,031$ & $4,674,634$ & $6,629,124$ \\
\hline
\end{tabular}


Note: From Hallock and Torok (2010). Data from Salary.com.

Table 3. CEO Compensation by Revenue

\begin{tabular}{|c|c|c|c|c|c|c|c|c|c|c|c|c|}
\hline & \multicolumn{6}{|c|}{ Cash Compensation } & \multicolumn{6}{|c|}{ Total Compensation } \\
\hline & $10^{\text {th }}$ & $25^{\text {th }}$ & Mean & Median & 75th & 90th & $10^{\text {th }}$ & $25^{\text {th }}$ & Mean & Median & 75th & 90th \\
\hline $0-<116$ & 326,774 & 396,000 & 616,804 & 521,703 & 765,290 & 975,849 & 449,349 & 676,779 & $1,382,037$ & $1,034,623$ & $1,631,245$ & $2,500,199$ \\
\hline $116-<219$ & 330,000 & 412,961 & 694,353 & 560,800 & 765,164 & $1,090,000$ & 418,168 & 621,750 & $1,465,745$ & $1,043,271$ & $1,501,970$ & $2,906,560$ \\
\hline $219-<360$ & 385,467 & 500,000 & 827,883 & 700,625 & 967,500 & $1,418,027$ & 521,101 & 807,011 & $1,787,558$ & $1,309,888$ & $2,138,803$ & $3,562,378$ \\
\hline $360-<600$ & 473,525 & 642,310 & $1,041,286$ & 897,188 & $1,090,939$ & $1,690,000$ & 726,737 & $1,067,464$ & $2,218,387$ & $1,694,451$ & $2,905,494$ & $4,158,242$ \\
\hline $600-<912$ & 530,173 & 690,000 & $1,163,253$ & 948,147 & $1,334,500$ & $1,741,250$ & 854,755 & $1,484,095$ & $2,729,881$ & $2,118,466$ & $3,234,420$ & $4,677,025$ \\
\hline $912-<1371$ & 638,230 & 838,235 & $1,452,193$ & $1,223,614$ & $1,723,000$ & $2,399,341$ & $1,078,276$ & $1,681,375$ & $3,246,883$ & $2,648,624$ & $4,031,500$ & $6,461,061$ \\
\hline $1371-<2209$ & 727,282 & $1,000,000$ & $1,616,560$ & $1,421,101$ & $1,950,913$ & $2,977,725$ & $1,535,356$ & $2,249,450$ & $4,118,238$ & $3,632,436$ & $5,238,242$ & $7,186,328$ \\
\hline $2209-<3974$ & 800,000 & $1,031,279$ & $2,037,876$ & $1,703,739$ & $2,440,838$ & $3,750,000$ & $1,567,596$ & $2,664,599$ & $5,434,129$ & $4,662,380$ & $6,702,930$ & $9,479,940$ \\
\hline $3974-<9637$ & 900,000 & $1,233,333$ & $2,264,928$ & $1,875,000$ & $3,008,750$ & $4,325,333$ & $2,114,767$ & $3,315,934$ & $6,673,713$ & $6,108,194$ & $8,477,317$ & $12,900,000$ \\
\hline$\geq 9637$ & $1,000,000$ & $1,694,000$ & $3,334,802$ & $3,025,857$ & $4,468,336$ & $7,016,500$ & $4,223,182$ & $6,478,689$ & $11,600,000$ & $11,300,000$ & $16,100,000$ & $25,000,000$ \\
\hline
\end{tabular}

Note: From Hallock and Torok (2010). Data from Salary.com. 
Table 4: Breakdown of Empirical Research on Executive Compensation (Sample)

Panel A: Studies which do not use a log-transformation on the dependent variable

\begin{tabular}{|c|c|c|c|c|}
\hline No FE & Industry FE & Firm FE & CEO FE & Diff in Diff or Lagged term \\
\hline Antle and Smith 1986 & $\begin{array}{l}\text { Aboody, Barth, and } \\
\text { Kaszmik } 2006\end{array}$ & $\begin{array}{l}\text { Comprix and Muller } \\
2006\end{array}$ & $\begin{array}{c}\text { Aggarwal and Samwick } \\
1999 \mathrm{~b}\end{array}$ & Aggarwal and Samwick 1999 \\
\hline Baker and Hall 2004 & Core et al1999 & Hartford and Li 2007 & $\begin{array}{l}\text { Aggarwal and Samwick } \\
2003\end{array}$ & Almazan et al 2005 \\
\hline $\begin{array}{l}\text { Carpenter and Sanders } \\
2002\end{array}$ & Garen 1994 & & Cichello 2005 & Anderson and Bizjak 2003 \\
\hline Chen et al 2006 & & & Hartzell and Starks & Boschen and Smith 1995 \\
\hline \multirow[t]{8}{*}{ Dee et al 2005} & & & Murphy 1985 & David et al 1998 \\
\hline & & & & Frye et al 2006 \\
\hline & & & & Garvey and Milbourn 2003 \\
\hline & & & & Girma et al 2007 \\
\hline & & & & Hambrick and Finkelstein 1995 \\
\hline & & & & Jensen and Murphy 1990 \\
\hline & & & & Lippert and Moore 1994 \\
\hline & & & & Rajgopal et al 2006 \\
\hline
\end{tabular}


Table 4: Breakdown of Empirical Research on Executive Compensation (Sample)

Panel B: Studies which use a log-transformation on the dependent variable

\begin{tabular}{|c|c|c|c|c|}
\hline No FE & Industry FE & Firm FE & CEO FE & Diff in Diff or Lagged term \\
\hline Ang et al 2003 & $\begin{array}{l}\text { Chhaocharia and } \\
\text { Grinstein } 2009\end{array}$ & $\begin{array}{c}\text { Bertrand and } \\
\text { Mullainathan 2001 }\end{array}$ & & Abowd 1990 \\
\hline \multirow[t]{6}{*}{ Cosh and Hughes 1997} & Core and Guay 1999 & $\begin{array}{l}\text { Bebchuk and } \\
\text { Grinstein } 2005\end{array}$ & & Becker 2006 \\
\hline & Fattorusso et al 2007 & Cornett et al 2008 & & Coughlan and Schmidt 1985 \\
\hline & Hall and Murphy 2002 & $\begin{array}{c}\text { Cunat and Guadalupe } \\
2009\end{array}$ & & Gibbons and Murphy 1990 \\
\hline & Hallock 1997 & $\begin{array}{c}\text { Gabaix and Landier } \\
2008\end{array}$ & & Hall and Knox 2006 \\
\hline & & Hallock 2002 & & Hall and Liebman 1998 \\
\hline & & Kostiuk 1990 & & $\begin{array}{l}\text { Kato and Kubo } 2006 \\
\text { Leonard } 1990\end{array}$ \\
\hline
\end{tabular}


About the Authors:

Beth Florin is Managing Director of Pearl Meyer and Partners and leads the Survey and Employee Compensation Practice. She has specialized experience in the design, development and implementation of broad-based compensation programs and total remuneration compensation surveys. She was a cofounder of Executive Alliance, a technology industry compensation consultancy that was acquired by Clark Consulting in 2001. Prior to that, she was a Senior Human Resource Consultant with William M. Mercer, Incorporated's High Tech Compensation Practice and held human resource positions at Data General Corporation. She is a graduate of the University of Florida and holds and M.S. in Human Resource Management and Research Methodology from Cornell University. She is a member of the Dean's Advisory Council at the ILR School at Cornell and is a member of the Board of the Compensation Research Initiative (CRI) at Cornell.

Kevin F. Hallock is Professor of Labor Economics and of Human Resource Studies and Director of the Compensation Research Initiative (CRI) at the ILR School at Cornell University. He is also a research associate at the National Bureau of Economic Research (NBER), a senior fellow for executive compensation, board compensation and board practices at The Conference Board and a member of the Board of Directors at WorldatWork. His current research includes projects on executive and director compensation, the valuation of stock options and the design of compensation systems. He earned a B.A. in economics from the University of Massachusetts at Amherst and a Ph.D. in economics from Princeton University.

Douglas Webber is a Ph.D. student in Economics at Cornell University and is being funded on a National Science Foundation Fellowship. He is a member of the Cornell Higher Education Research Institute (CHERI) and the Compensation Research Initiative (CRI) at Cornell. He is a graduate of the University of Florida. His research interests are in compensation design and the economics of education.

${ }^{1}$ See for example Devers, Cannella, Reilly and Yoder (2007) and Murphy (1999) for recent reviews.

${ }^{2}$ One other reason for the dramatic increase in the use of options could have been due to the accounting treatment of the options. Until recently, most standard employee options did not have to count as an expense in the company balance sheet.

${ }^{3}$ See Kay and Van Putten (2007) for a rejoinder written by experienced practitioners in the field.

${ }^{4}$ The subject of how to value stock options for executives and other employees is an interested issue for debate. We do not focus on it in this paper. The interested reader can find discussion 
of this in Lambert, Larcker and Verrecchia (1991), Hall and Murphy (2002) and Hallock and Olson (2010).

${ }^{5}$ Recall that for most studies, researchers don't use the stock options data from this table but use the stock option grants table that appears later in proxy statements.

${ }^{6}$ Hallock and Olson (2010) provide a much more comprehensive description of data sources for research on executive compensation and employee stock options.

${ }^{7}$ Substantially more detail than provided in this section can be found in Hallock and Torok (2010). This section is based on that work.

${ }^{8}$ There are some exceptions including Hallock $(1997,1999)$ who investigates the relationships between "reciprocally interlocking boards of directors" (CEO of firm A is a member of firm B's board at the same time CEO of firm B is a member of firm A's board) and executive compensation.

${ }^{9}$ Defined as the net income plus interest, divided by the average total assets over the previous year (adjusted for the corporate tax rate).

${ }^{10}$ Calendar-year return (dividends plus capital gains) per share of common stock

${ }^{11}$ Note that the axes are in logarithms so a step from 3 to 4 is, for example, substantially smaller than a step from 7 to 8 . 